\title{
Americans at Armageddon
}

\author{
Guy Middleton
}

\author{
Digging Up Armageddon: The Search for the Lost City of \\ Solomon \\ by Eric Cline \\ Princeton University Press, 424 pp., \$35.00.
}

$\mathrm{I}$ $\mathrm{N}$ POPULAR CUlTURE, the term Armageddon has come to be associated with cataclysmic, world-ending events, such as an asteroid strike or nuclear war. Less widely known is the origin of the name, or its single mention in the New Testament in a section of Revelation describing the great battle at the end of days. Armageddon, the Hill of Megiddo, is where the battle will take place. $^{1}$

The ancient city of Megiddo was located in the western end of the Jezreel Valley. Mount Carmel and the Mediterranean Sea lay to the west, and Beth-Shan and the Jordan River to the east. During the Bronze Age, Megiddo became a flourishing regional center. When the Egyptian pharaoh Thutmose III conquered it around $1468 \mathrm{BCE}$, his spoils included almost 900 chariots, 500 bows, 200 suits of leather armor, 2,000 horses, and 25,000 other animals, including sheep, goats, and cows. An account of the battle and the complete list of booty is inscribed on the walls of the Temple of Amun at Karnak. ${ }^{2}$ The city recovered and remained important throughout the first half of the first millennium BCE, the Iron Age, until it was finally abandoned around 586 BCE. The city's ties to the Egyptian empire and its association with the Old Testament king Solomon have always lent the site a special appeal among archaeologists.

Solomon ruled Israel from around 970 to 931 BCE. ${ }^{3}$ He was also a builder, responsible for the construction of the First Temple in Jerusalem, and under his rule Israel prospered, engaging in trade and diplomacy with neighboring kingdoms. ${ }^{4}$ In addition to the Temple, Solomon built 40,000 stalls for his chariot horses and 12,000 horsemen. ${ }^{5}$ These horsemen and 1,400 chariots were distributed throughout his chariot cities, of which Megiddo was one. ${ }^{6}$ Though most scholars see no reason to deny that there was a King Solomon, traces of a powerful Israel as described in the Old Testament have been difficult to find, despite years of searching.? The excavations at Megiddo have played a role in this search.
$\mathrm{E}$ RIC CLINE'S Digging Up Armageddon tells the story of the team from the University of Chicago that began digging at Megiddo during the mid-1920s. The book opens with a telegram sent in June 1928 by P. L. O. Guy, field director at Megiddo, to James Henry Breasted, the director of the University of Chicago's Oriental Institute.

FIRST KINGS NINE FIFTEEN TO NINETEEN AND TEN TWENTYSIX STOP STRATUM FOUR APPARENTLY CORRESPONDS STOP BELIEVE HAVE FOUND SOLOMON'S STABLES ABOUT FORTY BY TWENTY METRES WITH ACCESS BY SEVEN METRE STREET N TWELVE AND THIRTEEN. ${ }^{8}$

Though occasionally disputed, later work has confirmed that these remains were indeed stables, complete with mangers and hitching posts. ${ }^{9}$ It has also become clear that the stables were built much later than Solomon's time, possibly from the mid-ninth or even the first half of the eighth century BCE. ${ }^{10}$ While Guy would have known that horses and chariots were important to later rulers, the temptation to associate them with Solomon was compelling.

Cline's book was originally intended to be a straightforward volume on the archaeology of Megiddo, a site where he had worked for twenty years. ${ }^{11}$ But during the course of his research, he realized that there was another layer to the history at Megiddo. The people who worked there and their stories, Cline discovered, were just as interesting as the site itself. Assembled from diaries, letters, cablegrams, and other archival sources, Digging Up Armageddon recounts the story of the Chicago expedition, from its inception in 1925 until the early years of the Second World War.

Looming large in the story is the figure of Breasted, who founded the Oriental Institute in 1919 with funding from John D. Rockefeller. ${ }^{12}$ The following year, Breasted visited the Middle East looking for new sites. Even though he had been unable to access Megiddo on his visit, it was his idea to dig there. He obtained an excavation permit from the Department of Antiquities in British Mandate Palestine, along with financial backing from Rockefeller, and 
hired Clarence S. Fisher as his field director. Fisher was an experienced digger, having excavated at Nippur in Mesopotamia and directed excavations in Egypt.

Work began at Megiddo in 1925.

Breasted remained closely involved with the Megiddo project until his death in 1935 at the age of 70 . After visiting Megiddo with Breasted in 1929, Rockefeller gave him US\$100,000-about US\$1.5 million in today's moneyfor his own use as a token of Rockefeller's "admiration for what you have done and are doing [and] my genuine affection for you." ${ }^{13}$ Cline notes that Breasted died before reading a letter from Rockefeller explaining that he could no longer fund the Oriental Institute and its projects.

Cline's sketch of the early days at Megiddo portrays how the project got underway, with the first team of four men camping onsite in six "luxuriously furnished" tents "complete with white bed sheets, finely woven grass carpets on the floors, and a small washstand for each of the Americans." ${ }^{\prime 4}$ Each day the men were treated to five-course lunches, seven-course dinners, and afternoon tea. Although well stocked with creature comforts, the site was also malarial and many of the expedition members fell ill. When the British High Commissioner Herbert Plumer visited the new project, malaria had brought work to a halt. ${ }^{15}$ Eventually a substantial dig house was built, finished in 1926.

There was friction among team members, Cline notes, from the beginning of the project. When selecting the initial field director, Breasted could not choose between Fisher and the geologist Daniel Higgins. ${ }^{16}$ Breasted described Fisher as "almost neurotic" and liable to "go off the deep end," while Higgins was abrasive and lacked archaeological experience. The pair subsequently engaged in something of a tussle over the leadership of the project and Higgins was soon relieved of his post. ${ }^{17}$ Fisher was let go in 1927, officially on health grounds, after having suffered recurring bouts of malaria. ${ }^{18}$

Another divisive figure was Ralph Parker, appointed as superintendent in 1927. Parker was an anti-Semite, and he was often rough with the Egyptian and local workmen, and the locals generally. ${ }^{19}$ On one occasion he kicked a man in the shin and injured him; on another, he kicked a small boy to the ground. The incident led to strikes and protests during which Parker and another team member were attacked. Despite these encounters, Parker lasted the longest of all the team members at Megiddo, working there from 1927 to 1939, and then from the end of the war in 1945 until 1954.

Ruby Woodley, who worked at Megiddo from 1926 to 1928 as a secretary and housekeeper, also became a target for scorn. Guy, the second field director, commented that Woodley "has a character which makes her an extremely dangerous member of my staff." ${ }^{20}$ Apart from being overprotective of her work, she purportedly pursued the three much younger single men on the team. Guy suggested the evidence combined "to make a story of intrigue, hintings and devious dealings." Woodley was also let go.
A later scandal, known as the May affair, involved the illegal removal of antiquities by Herbert May, a biblical scholar who worked at the site from 1931 to 1934. While attempting to leave from Haifa in July 1934, May failed to declare a collection of potsherds, flints, and other artifacts. He was detained and fined £10. Guy made no effort to defend him and an investigation was conducted. May was later allowed to leave, catching up with his ship in Beirut. After May's departure, Guy wrote to Breasted, dispatching a letter that Breasted later described as "the most sordid document to ever reach this office."ㄹ Sadly, this correspondence is missing from the archives. As it turned out, Guy did not last much longer than May. The letter to Breasted was seen as the latest in a long series of transgressions, and Guy was let go in August 1934. ${ }^{22}$

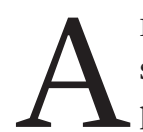
LTHough Digging Up Armageddon is primarily a social history of an archaeological project, it also provides some idea of how the archaeology at the site was being done. When the work began at Megiddo, the notion of scientific archaeology was still fairly new, building on the influential work of Augustus Pitt-Rivers at Cranborne Chase, England, and Flinders Petrie in Egypt and the Near East in the late nineteenth century. ${ }^{23}$ Excavation is a process of revelation, but also one of destruction. It is only the meticulous recording of the excavations and the location of any finds that allows later archaeologists to understand the site.

When archaeologists work on a site, they can excavate horizontally, which allows for the development of site plans and maps for individual periods, or they can focus on vertical stratigraphy, which provides a glimpse of the site through time. At Megiddo, Cline notes, can be found "the remains of at least twenty ancient cities, built one on top of another over the course of nearly five thousand years."24 Fisher, whom Cline describes as one of "the best practitioners of his time," began by excavating the site horizontally, attempting to reveal one layer, or city, at a time. ${ }^{25}$ As a result, there is now nothing left of the top two levels from the original site: Strata I and II, from the Persian and Neo-Babylonian periods. The site was soon divided into 25-meter squares marked out with pegs and laid out along the cardinal directions, enabling finds and features to be labeled and precisely mapped. ${ }^{26}$ The team kept detailed records, including photographs, and made topographic plans of each level in turn. Fisher wrote that "[b]y this method one keeps in touch with the historical sequence and feels tremendous satisfaction in seeing the story of the hill develop."27 Most of the actual digging and labor was done by "hordes" of local workmen, including children, with experienced Egyptian foremen overseeing operations. ${ }^{28}$

Two further developments in the study of the site occurred under the leadership of Guy. The first was the use of aerial photography using hydrogen-filled balloons with purpose-built cameras attached and triggered from the 
ground..$^{29}$ Although aerial photography had been around for some time-Stonehenge had been photographed from a balloon-mounted camera in $1906^{30}$-this was a novel approach in Near Eastern archaeology. The second development was the introduction of the Munsell Book of Color, sent to Guy by Breasted. ${ }^{31}$ This book, though not created with archaeology in mind, provided an objective way of identifying and recording soil color in excavations. It is now a standard part of the archaeologist's toolkit.

Guy's successor as field director, Gordon Loud, changed the excavation strategy at Megiddo, digging several large exploratory trenches down to the bedrock in an effort to establish the chronology of the site and locate the most promising areas for further investigation. ${ }^{32}$ By the end of 1935, the expedition had reached Strata VIII, IX, and X, dating from the Late and Middle Bronze Age. ${ }^{33}$ One major find in the eastern dig was a bronze statuette with gold leaf representing a Canaanite god..$^{34}$ Other substantial finds, including massive walls, a shell floor, and a hoard of gold objects, suggested the existence of a palace. ${ }^{35}$ Objects with Egyptian hieroglyphs dated this Stratum VIII palace to the Eighteenth Dynasty, around 1550 to 1295 BCE, and confirmed the importance of Megiddo as a regional center.

$\mathrm{R}$ EADING Digging Up Armageddon feels somewhat like entering the world of Agatha Christie's murder mysteries, falling between the devastations of the First and Second World Wars in a Middle East still dominated by colonial Europeans and adventurous Americans. The atmosphere perhaps most closely resembles that of Christie's 1936 novel Murder in Mesopotamia, which was based on her experiences in the region, including her visit to the dig at Ur, where she met her husband, the archaeologist Max Mallowan. As with Christie's story, the action at Megiddo mostly concerns Americans and Europeans, rather than Arabs. The political and social background of British colonialism-Palestine was under British rule from the end of the First World War until 1948-and the creation of Israel, is ever-present in the book, and the conflicts among Arabs, Jews, and the British all had an impact on archaeological research. ${ }^{36}$ The colonialist hierarchy is always clear: the Arabs did the hard work, sometimes numbering in the hundreds onsite, but it was the small group of foreigners, including the Egyptian foremen, who ran the show.

During the Arab-Israeli War in 1948, the dig house at Megiddo was abandoned, looted, and stripped of anything useful, including its bathroom tiles. ${ }^{37}$ Compensation was eventually paid to the Oriental Institute, and in 1955 the house was signed over to the Israeli government. The Chicago project at Megiddo was now at an end. But this was not the end of archaeological exploration at Megiddo. Cline was part of a team from Tel Aviv University digging at Megiddo from 1994 to 2014, and eventually became co-director of the expedition. His long relationship with the site gives him a unique perspective on both the archae- ology and the workings of an archaeological expedition at Megiddo. Digging Up Armageddon is an authoritative guide to the Chicago project during the interwar years, its internal politics, and its fascinating cast of characters.

Guy Middleton is a Visiting Fellow in the School of History, Classics, and Archaeology at Newcastle University.

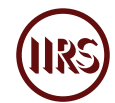

1. Revelations 16:16. On Revelations, see David Barr, "The Apocalypse of John," in The Blackwell Companion to the New Testament, ed. David Edward Aune (Chichester: John Wiley, 2008).

2. Translated in James Pritchard, ed., The Ancient Near East:An Anthology of Texts and Pictures, vol. 1 (Princeton: Princeton University Press, 1958), 175-82. See also Betsy Bryan, "The Eighteenth Dynasty before the Amarna Period (c.1550-1352 BC)," in The Oxford History of Ancient Egypt, ed. Ian Shaw (Oxford: Oxford University Press, 2000), 218-71.

3. On Solomon, see Isaac Kalimi, Writing and Rewriting the Story of Solomon in Ancient Israel (Cambridge: Cambridge University Press, 2018).

4. 1 Kings 6.

5. 1 Kings $4: 26$.

6. 1 Kings 9:19 and 10:26.

7. See Israel Finkelstein and Neil Asher Silberman, The Bible Unearthed: Archaeology's New Vision of Ancient Israel and the Origin of Its Sacred Texts (New York: Touchstone, 2002), 128ff., especially 135-45.

8. Eric Cline, Digging Up Armageddon: The Search for the Lost City of Solomon (Princeton: Princeton University Press, 2020), 1-2.

9. Cline, Digging Up Armageddon, 89-91.

10. Cline, Digging Up Armageddon, 91.

11. Cline has already written on Megiddo in his book The Battles of Armageddon: Megiddo and the Jezreel Valley from the Bronze Age to the Nuclear Age (Ann Arbor: The University of Michigan Press, 2002).

12. On Breasted, see Jeffrey Abt, American Egyptologist: The Life of James Henry Breasted and the Creation of His Oriental Institute (Chicago: University of Chicago Press, 2011).

13. Cline, Digging Up Armageddon, 96.

14. Cline, Digging Up Armageddon, 25.

15. Cline, Digging Up Armageddon, 26.

16. Cline, Digging Up Armageddon, 17 and chapter 3.

17. Cline, Digging Up Armageddon, 36-39.

18. Cline, Digging Up Armageddon, 61.

19. Cline, Digging Up Armageddon, 103-105.

20. Cline, Digging Up Armageddon, 76.

21. Cline, Digging Up Armageddon, 176.

22. Earlier, the Guys had already behaved appallingly to the Mays. When the Mays announced that they were expecting a baby, Guy had given an "insulting reaction," while Mrs. Guy 
had said Mrs. May should have told her of the pregnancy earlier, so she "could have informed Mrs May of methods of getting rid of the child" before Mr. May knew of it. Cline, Digging Up Armageddon, 182.

23. Philip Barker, Techniques of Archaeological Excavation (London: Routledge, 1993), 36; and Alice Stevenson, “"We Seem to Be Working in the Same Line': A. H. L. F. Pitt-Rivers and W. M. F. Petrie" Bulletin of the History of Archaeology 22, no. 1 (2012): 4-13, doi:10.5334/bha.22112.

24. Cline, Digging Up Armageddon, xv.

25. Cline, Digging Up Armageddon, 13.

26. Cline, Digging Up Armageddon, 49. This system is still in use at the site but with 5-meter squares.

27. Cline, Digging Up Armageddon, 51.

28. Cline, Digging Up Armageddon, 49.

29. Cline, Digging Up Armageddon, 128-31; figure 25.
30. J. Capper, "XXIII.-Photographs of Stonehenge, as Seen from a War Balloon," Archaeologia 60, no. 2 (1907): 571, doi:10.1017/s0261340900005208. See also Włodzimierz Rączkowski, "Aerial Archaeology," in Field Archaeology from Around the World, ed. Martin Carver, Bisserka Gaydarska, and Sandra Montón-Subías (Cham: Springer, 2015), 19-25.

31. Cline, Digging Up Armageddon, 132.

32. Cline, Digging Up Armageddon, 218.

33. Cline, Digging Up Armageddon, 224.

34. Cline, Digging Up Armageddon, 224.

35. Cline, Digging Up Armageddon, 245-47.

36. See for example Tom Segev, One Palestine, Complete: Jews and Arabs under the British Mandate (London: Abacus, 2001).

37. Cline, Digging Up Armageddon, 295.

DOI: $10.37282 / 991819.22 .2$ 